\title{
Epipelagic copepod distributions in the eastern equatorial Pacific during the weak La Niña event of 2001
}

\author{
PRITHA TUTASI ${ }^{1,2}$, SERGIO PALMA $^{1}$ and MARIO CÁCERES ${ }^{3}$ \\ ${ }^{1}$ Pontificia Universidad Católica de Valparaíso, P.O. Box 1020, Valparaíso, Chile. E-mail: prithalila@ @mail.com \\ ${ }^{2}$ Centro de Biodiversidad (CENBIO), Universidad de Guayaquil, P.O. Box 09-01-471, Guayaquil, Ecuador. \\ ${ }^{3}$ Universidad de Valparaíso, P.O. Box 5080, Viña del Mar, Chile.
}

\begin{abstract}
SUMMARY: We determined the distribution and abundance of pelagic copepods in the eastern equatorial Pacific between the coast of Ecuador and the Galapagos Islands under oceanographic conditions associated with the weak La Niña event of 2001. In September-October 2001, negative anomalies of sea surface temperature from this event still remained in the eastern equatorial Pacific, mainly between Ecuador and the Galapagos Islands. The event allowed the incursion of the Humboldt Current farther north and of the Equatorial Undercurrent into the study area, favouring a strong Equatorial Front and upwelling processes. There was evidence of mesoscale eddies in the study area and of the presence of the South Equatorial Current going westward at about $1^{\circ} \mathrm{N}$. We identified 107 copepod species and analyzed the distribution of the 10 most abundant ones: Oncaea venusta, Subeucalanus pileatus, S. crassus, S. subtenuis, Paraeucalanus attenuatus, Pleuromamma borealis, Scolecithrix danae, Clausocalanus farrani, Temora discaudata and Calanus chilensis. Copepod distribution and abundance exhibited marked latitudinal differences related to the oceanographic conditions; abundance was highest to the southeast of the Galapagos Islands. Oncaea venusta, Pleuromamma borealis, Calanus chilensis, and Subeucalanus subtenuis were the species that best defined the Equatorial Front and the upwelling process.
\end{abstract}

Keywords: epipelagic copepods, upwelling processes, La Niña event, Equatorial Front, eastern Equatorial Pacific Ocean.

RESUMEN: Distribución de Copépodos epipelágicos en el Pacífico eCuatorial oriental duRante el eVento DÉBIL DE LA NIÑa DE 2001. - Se determinó la distribución y abundancia de los copépodos epipelágicos en el Pacífico Ecuatorial Oriental, entre la costa de Ecuador e islas Galápagos, durante condiciones oceanográficas asociadas al evento débil de La Niña 2001. Al final de este evento (Septiembre-Octubre 2001), aun se registraban las anomalías de temperatura superficial en el Pacífico Ecuatorial Oriental, en el área de estudio. Este evento favoreció la incursión hacia el norte de la Corriente de Humboldt y la Subcorriente Ecuatorial, como también la intensificación del Frente Ecuatorial. Se evidenció la presencia de remolinos de mesoescala y de la Corriente Surecuatorial hacia el oeste, alrededor de $1^{\circ} \mathrm{N}$. Se identificaron 107 especies de copépodos y se analizó la distribución de las diez especies más abundantes (Oncaea venusta, Subeucalanus pileatus, S. crassus, S. subtenuis, Paraeucalanus. attenuatus, Pleuromamma borealis, Scolecithrix danae, Clausocalanus farrani, Temora discaudata y Calanus chilensis). La distribución y abundancia de estas especies presentó marcadas diferencias latitudinales asociadas a las condiciones oceanográficas, que mostraron las mayores densidades al sureste de las islas Galápagos. Oncaea venusta, Pleuromamma borealis, Calanus chilensis y Subeucalanus subtenuis fueron las especies que mejor definieron el Frente Ecuatorial y los eventos de surgencia.

Palabras clave: copépodos epipelágicos, surgencia, La Niña, Frente Ecuatorial, Pacifico ecuatorial oriental.

\section{INTRODUCTION}

Tropical systems offer an interesting example of the intensification of climate processes or changes because their boundaries expand or contract in function of such processes (Sharp, 2004). The eastern equatorial Pacific is characterized by variable oceanographic and atmospheric conditions, and is affected by sporadic warm El Niño and cold La Niña events (ENSO), which cause significant changes in the annual climate variability and influence the tropics on seasonal or interannual scales (Philander, 1990). Little is known about how these large-scale events 
influence plankton production and variability in the eastern equatorial Pacific, despite the recognized importance of planktonic organisms as indicator species of these changes (Carrasco and Santander, 1987; Jiménez, 2000).

This area of the Pacific receives tropical surface waters from the north and subtropical surface waters from the south. The resulting Equatorial Front is observed during the dry season (the austral winter). When southeasterly winds blow and north-westward flow of the Humboldt Current comes farther north, the front becomes more developed, contracting northwest from $2^{\circ} \mathrm{S}$ to $2^{\circ} \mathrm{N}$ between 80 and $90^{\circ} \mathrm{W}$. During the rainy season, due to the weakening of southerly winds and the arrival of warm, less salty waters from the north, the front weakens and retreats southward to off the Peruvian coast (Wyrtki, 1967; Jiménez, 1983; Okuda et al., 1983). The South Equatorial Current is the main surface current in the study area. It moves westward between $4^{\circ} \mathrm{N}$ and $10^{\circ} \mathrm{S}$. It is fed in the northeast by a branch of the North Equatorial Countercurrent and in the southeast by the Humboldt Current, which flows northward from Peru before veering west towards the Galapagos Islands, forming the southern boundary of the Equatorial Front (Wooster, 1969). In this area, biological studies have focused exclusively on the chlorophyll concentration, primary production measurements, euphausiids, and the volume of zooplankton (Brinton, 1962; Arcos, 1978; Cornejo and Antezana, 1979; Jiménez and Bonilla, 1980; Jiménez, 1983; Córdova, 1989; Torres and Tapia, 2000; Torres et al., 2004).

In recent decades, several researchers have used copepods to characterize oceanographic conditions and water masses (Björnberg, 1981; Beaugrand et al., 2002; Costello et al., 2006; McKinnon et al., 2008) because their short life cycles allow them to respond to seasonal changes (Hooff and Peterson, 2006; McKinnon et al., 2008). Moreover, copepods are known for their diversity and importance in the food web. They are the most abundant primary consumers throughout the oceans and the main food of several planktophagous fishes (e.g. herring, anchovy, sardine and corvine), fish larvae, and planktonic and benthic invertebrates (Björnberg, 1981).

Zooplankton have not been extensively studied in the eastern Tropical Pacific and very little attention has been paid to their composition, abundance, and distribution in relation to ENSO events. Arcos (1978) analyzed the distribution of planktonic biomass and copepods in the Gulf of Guayaquil during a high salinity period caused by lower contribution from the Guayas River. Arcos and Fleminger (1986) studied calanoid copepods from the eastern equatorial Pacific collected during the EASTROPAC cruises (1967-1968) performed during years with "normal" conditions. Simultaneously, Chen (1986) determined the vertical distribution of copepods in the eastern Tropical Pacific $\left(23^{\circ} \mathrm{N}-3^{\circ} \mathrm{S}, 90-120^{\circ} \mathrm{W}\right)$, whereas Dessier and Donguy (1987) analyzed the interannual variability of the surface copepods associated with the 1982-1983 El Niño to the west of the Galapagos Islands $\left(80-130^{\circ} \mathrm{W}, 16^{\circ} \mathrm{S}-8^{\circ} \mathrm{N}\right)$. Tutasi $(2005)$ identified 97 copepod species in coastal Ecuadorian waters during the La Niña event of 2001, determining some species to be possible indicators of La Niña.

Typical effects caused by La Niña and its impacts in the eastern equatorial Pacific are as follows: a) the thermocline and nutricline are higher-than-normal, favouring primary production and the other trophic levels; b) changes occur in the distribution of species; c) some species migrate, and d) copepods play a role in the trophic level. The present study analyzed the composition, distribution, and abundance of pelagic copepods in relation to the oceanographic conditions of the Equatorial Front and upwelling processes, observed in the eastern equatorial Pacific at the end of

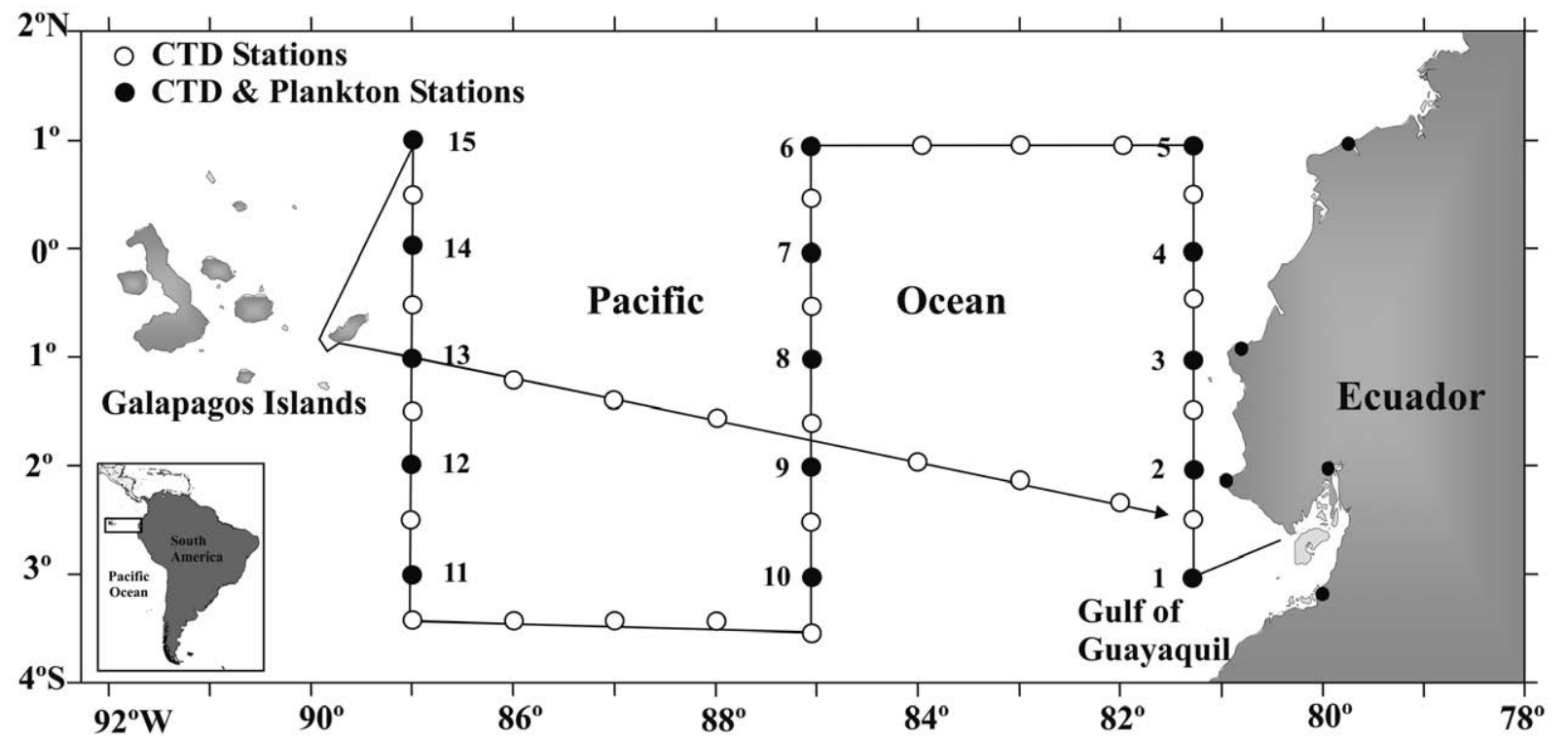

FIG. 1. - Study area indicating stations sampled during the oceanographic cruise CO-02-2001 from BAE "Orion” in September and October 2001. 
the La Niña event of 2000-2001. We hypothesize that this front plays a role in species distribution, and that characteristic groups of species could be arranged according to oceanographic conditions.

\section{MATERIALS AND METHODS}

The oceanographic cruise CO-02-2001 was performed from 17 September to 9 October 2001 onboard the BAE Orión of the Oceanographic Institute of the Ecuadorian Navy (INOCAR) in the eastern Equatorial Pacific. The study area stretched from the coast of Ecuador to the Galapagos Islands and 41 oceanographic stations were distributed along 6 transects between $1^{\circ} \mathrm{N}-3^{\circ} \mathrm{S}$ and $81-89^{\circ} \mathrm{W}$ (Fig. 1). At each station, we obtained vertical profiles $(0-500 \mathrm{~m}$ depth) of temperature and salinity with a CTD Seabird 19 Seacat. The data were processed using specialized software (Surfer 8 and Matlab 6.1) and vertical temperature and salinity profiles were created for 3 sections (coastal, $81^{\circ} \mathrm{W}$; central, $85^{\circ} \mathrm{W}$; oceanic, $89^{\circ} \mathrm{W}$ ) parallel to the Ecuadorian coast.

Historical geostrophic currents estimated from altimetry data were retrieved from the web site of NOAA CoastWatch (www.aoml.noaa.gov) in order to understand the main patterns of surface circulation that occurred during oceanographic sampling. Wind data were obtained from a meteorological station onboard and recorded at each of the 42 oceanographic stations. The dominant wind pattern observed in $80 \%$ of wind observations was north-eastward or north-westward, with an average speed of 10 knots, suggesting upwelling-favourable conditions during almost the total sampling time.

At 15 oceanographic stations distributed in 3 sections, zooplankton catches were made with oblique tows from $150 \mathrm{~m}$ to the surface at a speed of $1 \mathrm{~m} / \mathrm{s}$. Zooplankton samples were collected with 2 simple conical nets joined together $(60 \mathrm{~cm}$ diameter, $240 \mathrm{~cm}$ total length), one with a $335 \mu \mathrm{m}$ mesh and the other with a $600 \mu \mathrm{m}$ mesh; two samples were taken per station. The nets were equipped with flowmeters to estimate the volume of water filtered. Samples were fixed with formalin neutralized with borax at 5\%. The zooplankton samples were divided with the Folsom splitter to obtain representative aliquots of $50 \mathrm{~mL}$, and the specimens were quantified and standardized to 1000 $\mathrm{m}^{3}$. Copepod taxonomic classification was based on the specialized literature (Wilson, 1932; Grice, 1961; Dawson and Knatz, 1980; Björnberg, 1981; Mazzocchi et al., 1995). Observations and measurements were made with a calibrated microscope.

We also determined species abundance (ind $10^{-3} \mathrm{~m}^{-3}$ ) and its association with the oceanographic variables using a canonical correlation analysis (Hair et al., 1998). For this analysis, we calculated the weighted values of temperature and salinity between 0 and $150 \mathrm{~m}$ depth for each oceanographic station (Rosales, 1992), because the oceanographic data were measured at discrete depths. The data were processed using specialized software
(Statistica 7.1). To evaluate the significance of the variables, we used the statistical chi-squared test $\left(\chi^{2}\right)$. The abundance results were used to map the geographic distribution of species whose abundance exceeded $1 \%$ of the total analyzed. Moreover, Bray-Curtis Index was used for faunal similarity analyses among the most abundant species (Bloom, 1981). Species were grouped in assemblages using cluster analysis at the $65 \%$ level (bootstrap value) and the Ward method, using specialized software (Statistica 7.1).

During the time of sampling at sea, Sea Surface Temperature Anomalies between -0.5 and $-1.0^{\circ} \mathrm{C}$ and Equatorial Subsurface Temperature Anomalies between -1 and $-2.0^{\circ} \mathrm{C}$ dominated in the eastern Equatorial Pacific, as was shown by historical data retrieved from the website of Climate Prediction Centre (NOAA, 2001). These values were representative of La Niña event of 2001 that was still present in the eastern Pacific in September-November 2001. The Oceanic Niño Index (ONI) showed values associated with near neutral conditions, but they seemed to be representative of the central and western sides of the equatorial Pacific rather than the eastern side.

\section{RESULTS}

\section{Oceanographic conditions}

Surface temperature fluctuated between 19 and $25^{\circ} \mathrm{C}$ and salinity between 33.5 and 35.0 , revealing a well-developed Equatorial Front between continental Ecuador and the Galapagos Islands (Fig. 2). On the southern edge of the front, temperatures ranged from 19 to $21^{\circ} \mathrm{C}$ and salinity from 34 to 35 , whereas on the northern edge, they ranged from 24 to $25^{\circ} \mathrm{C}$ and 33.0 to 33.5 (Fig. 2). The surface distribution of anomalies (Fig. 3) showed lower temperatures (negative anomalies of $-1.5^{\circ} \mathrm{C}$ ) and higher salinity (positive anomalies of 0.5 ) in the southern sector and west of $83^{\circ} \mathrm{W}$, which was in agreement with the development of the La Niña event. On the northern edge, we observed no positive temperature anomalies, although the waters were warmer than on the southern boundary and negative salinity anomalies $(-0.2)$ were found.

Geostrophic velocities from altimetry (Fig. 4) averaged between 17 September and 9 October 2001 showed evidence of some rings and typical oceanic weak currents that developed during the cruise sampling.

The vertical temperature profiles showed a welldeveloped surface thermocline (Fig. 5). In the coastal section, the $15^{\circ} \mathrm{C}$ isotherm was located between 60 and $70 \mathrm{~m}$ depth. The $20^{\circ} \mathrm{C}$ isotherm (the upper limit of the thermocline) (Zambrano, 1998) was found between 20 and $30 \mathrm{~m}$ at the northern stations, rising at the southern stations and even reaching the surface at stations 9 and 11. In the central section, the $15^{\circ} \mathrm{C}$ isotherm was located at approximately $40 \mathrm{~m}$ on the southern boundary of the front, deepening latitudinally towards the north until 90 $\mathrm{m}$. Lowering of this isotherm could be associated with 

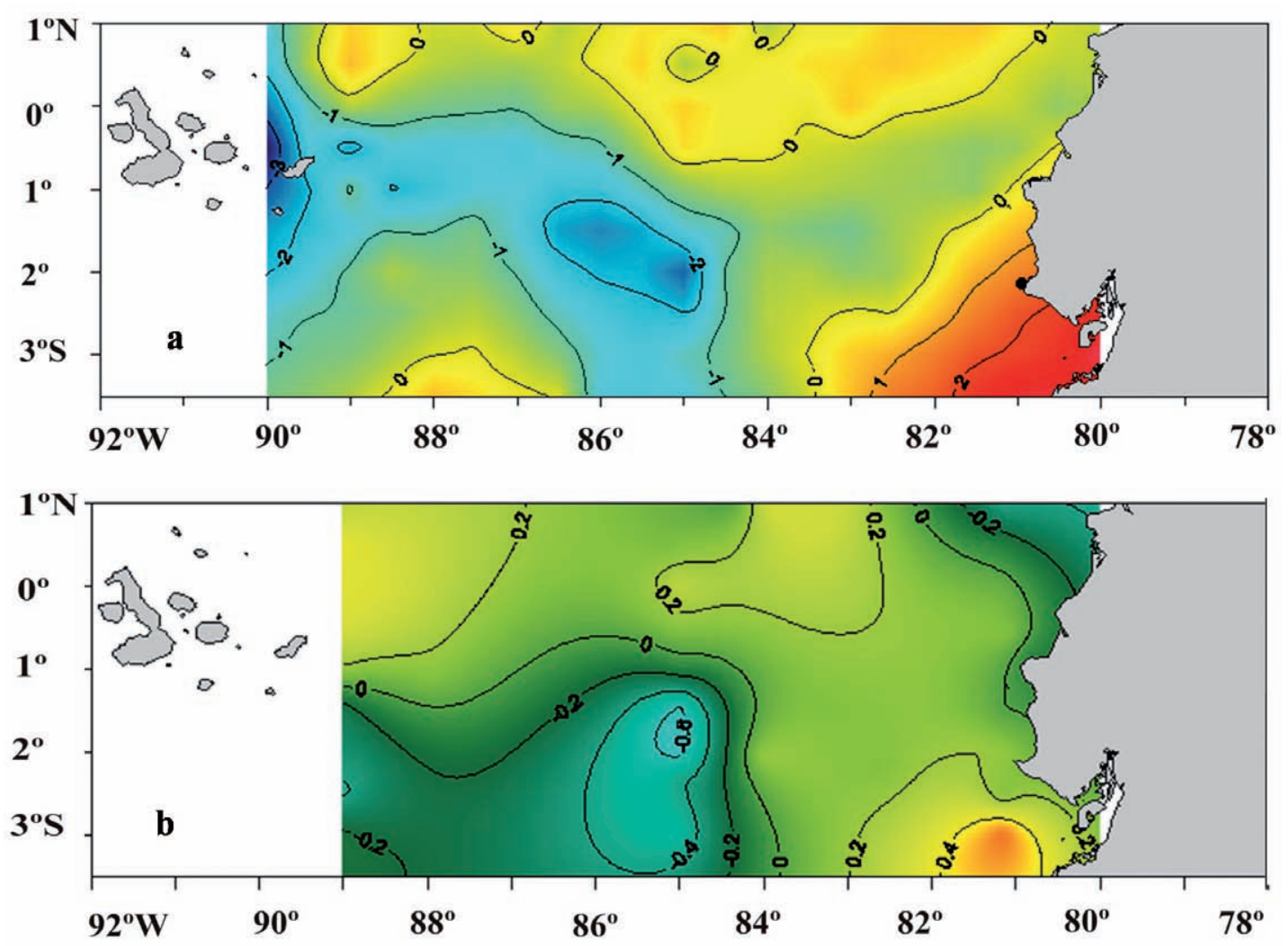

FIG. 2. - a) Sea surface temperature $\left({ }^{\circ} \mathrm{C}\right)$, b) Sea surface salinity in September and October 2001.
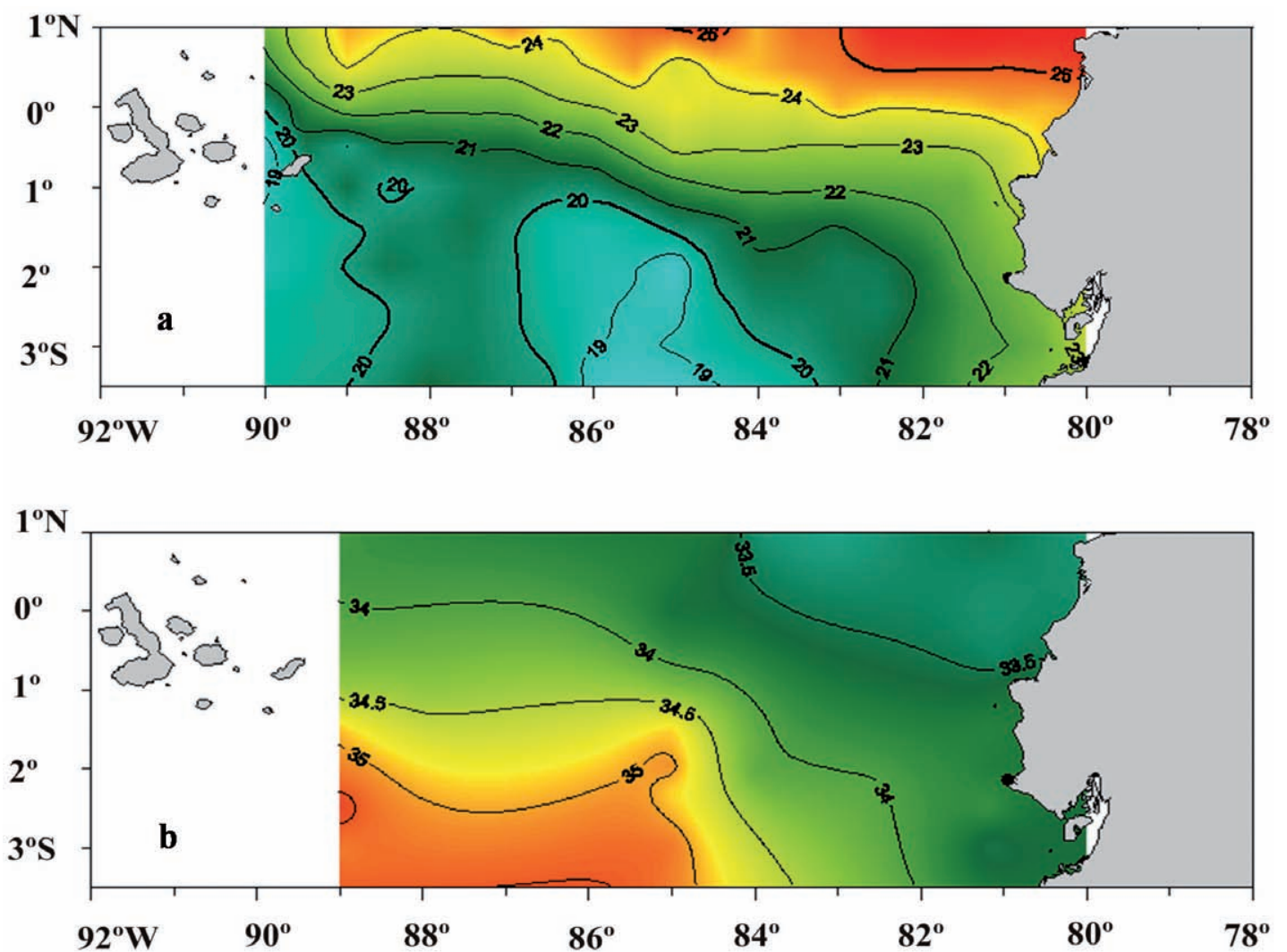

FIG. 3. - a) Sea surface temperature anomalies, b) Sea surface salinity anomalies in September and October 2001. 


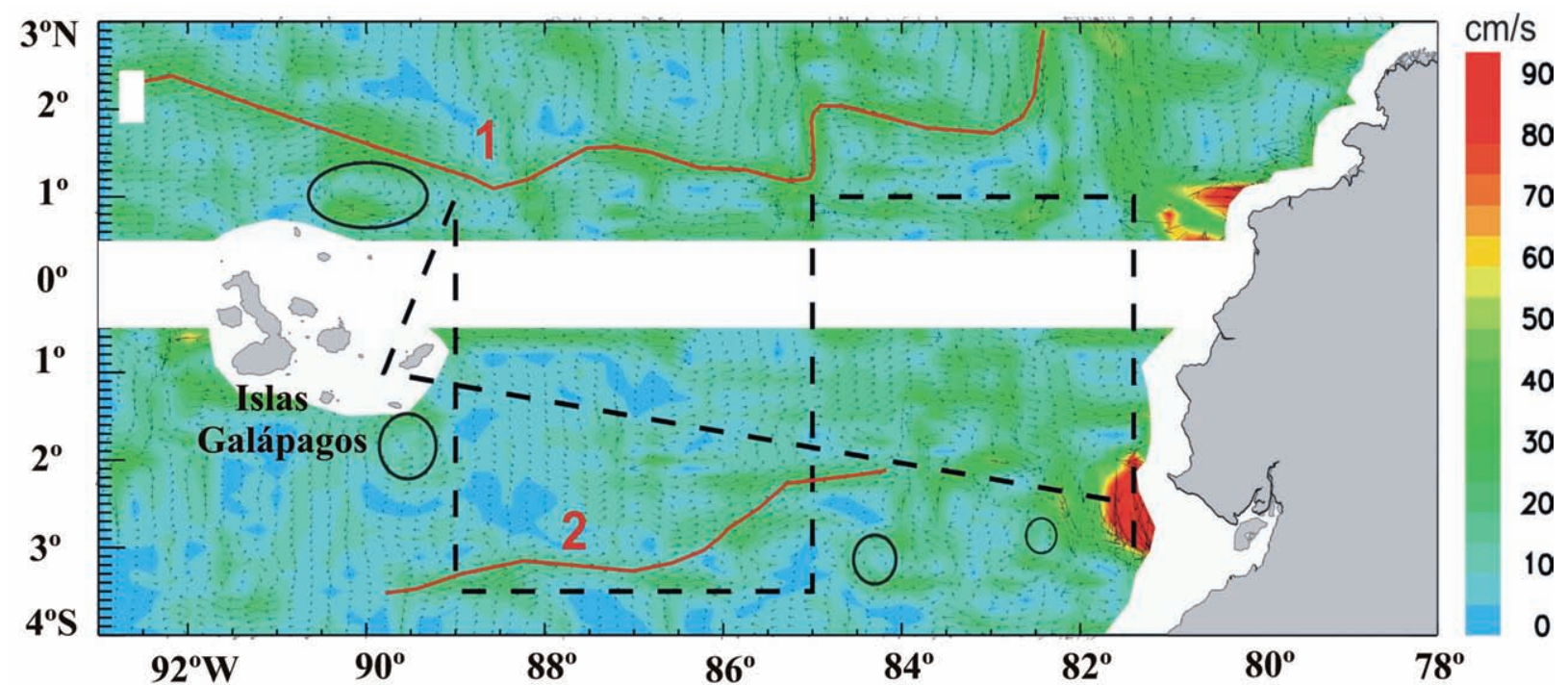

FIG. 4. - Mean geostrophic velocities from 17 September to 9 October 2001, computed from altimetry data available at the NOAA CoastWatch programme. Contours are magnitudes and arrows are directions. Dashed line is the approximate cruise track. Circles and ellipses represent oceanic mesoscale eddies formed in the vicinity of the cruise track. Red lines are the inferred trajectories of the westward South Equatorial Current (1) and the eastward Equatorial Undercurrent (2) extended to the surface. Low reliability of geostrophic estimates near the coast and along the equatorial fringe has been masked by a white band.

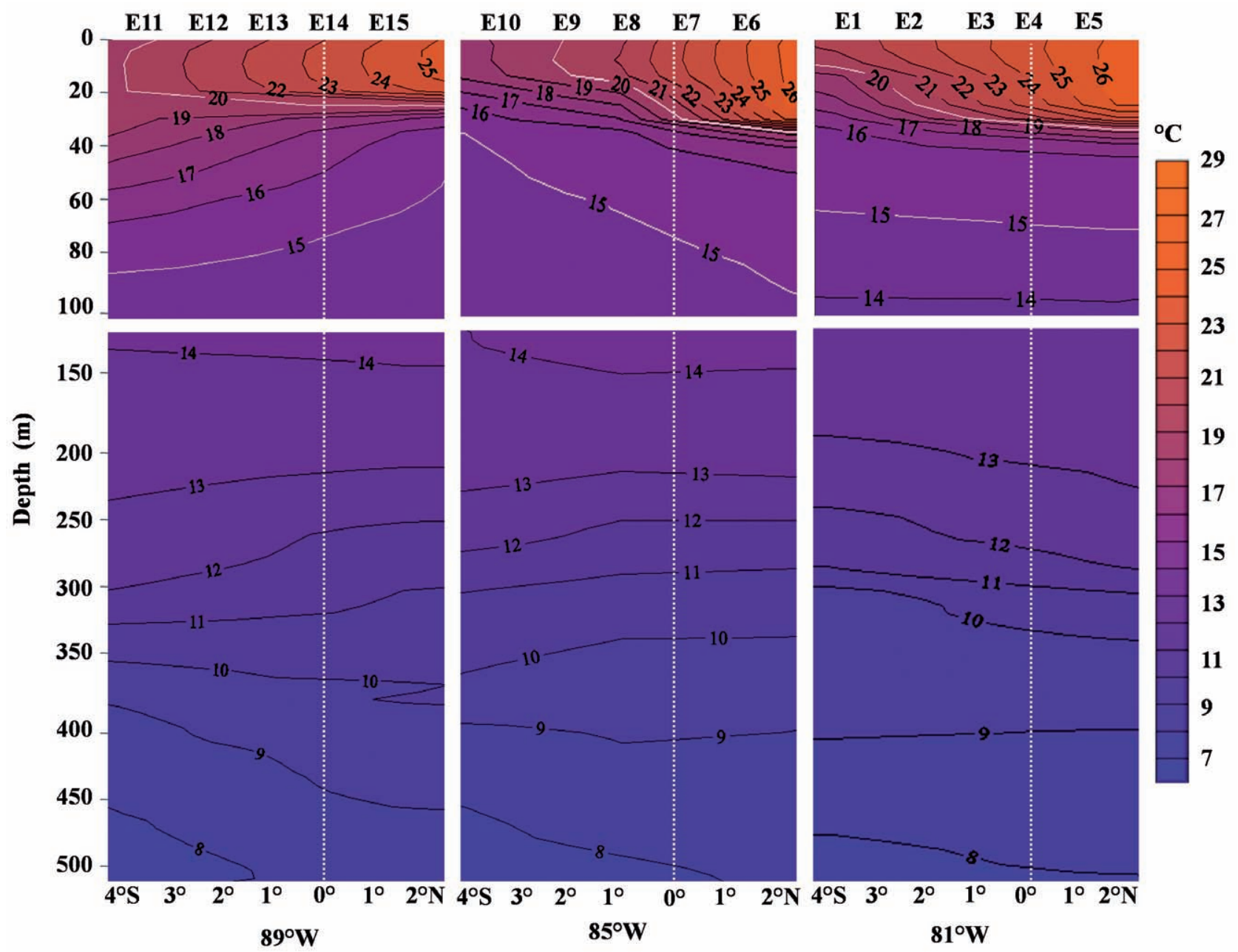

FIG. 5. - Vertical distribution of temperature in three longitudinal sections in September and October 2001. 


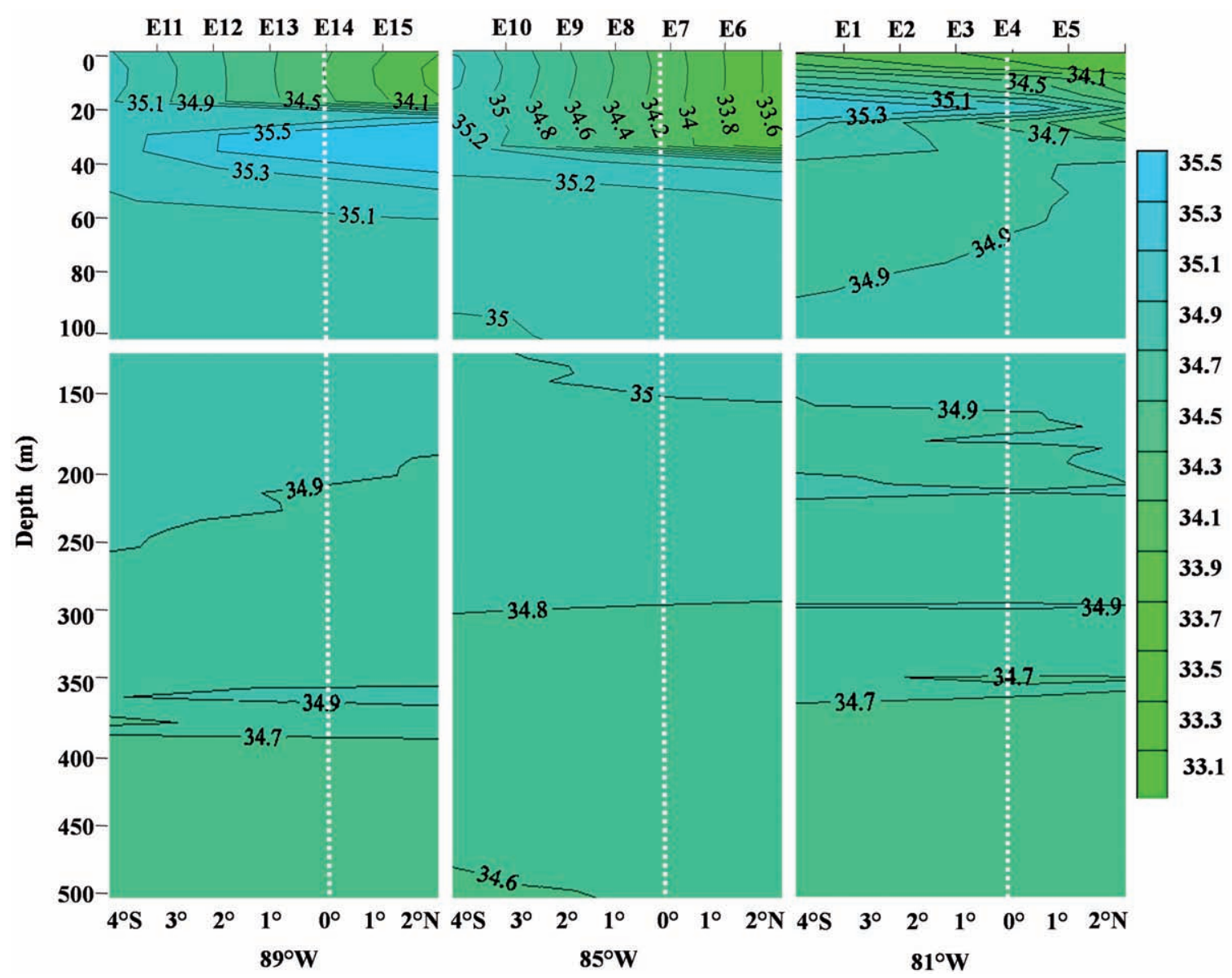

FIG. 6. - Vertical distribution of salinity in three longitudinal sections in September and October 2001.

downwelling induced by sharp meandering and acceleration of the South Equatorial Current (Fig. 4) in the northern region of the central section. In the oceanic section, the $15^{\circ} \mathrm{C}$ isotherm deepened at the southern limit to $85 \mathrm{~m}$, but rose to $60 \mathrm{~m}$ at the northern boundary. Rising on the southern side might be associated with the presence of mesoscale eddies and the presence of the branch of the Equatorial Undercurrent, both inducing upwelling. In both sections ( 85 and $89^{\circ} \mathrm{W}$ ), the $20^{\circ} \mathrm{C}$ isotherm exhibited a marked rise to the surface levels in the southern sector of the front due to upwelling processes.

Salinity values were high in the vertical distribution of the coastal section (Fig. 6), represented by the 35 isohaline with a subsurface halocline at $30 \mathrm{~m}$ depth. The central and oceanic sections were similar to patterns for temperature, with the halocline rising at the southernmost stations due to upwelling.

\section{Distribution and abundance}

We identified 49352 copepods corresponding to 107 species. Abundance was highest to the east of the Galapagos Islands (oceanic section), fluctuating between 5000 and 15000 ind $10^{-3} \mathrm{~m}^{-3}$ in the samples obtained with the 335- $\mu \mathrm{m}$ net, and between 2000 and 7000 ind
$10^{-3} \mathrm{~m}^{-3}$ in the samples taken using the $600-\mu \mathrm{m}$ net. Oncaea venusta, Subeucalanus pileatus, $S$. crassus, $S$. subtenuis, Paraeucalanus attenuatus, Pleuromamma borealis, Scolecithrix danae, Clausocalanus farrani, Temora discaudata, and Calanus chilensis were the 10 most abundant species ( $>1 \%$ of the total) collected with both types of net. These 10 species represented $60 \%$ of the total analyzed (Table 1); the other $40 \%$ corresponded to the remaining 97 species (Table 2).

Depending on the mesh size, we observed differences in the copepod species composition and abundances in the catches. In fact, we collected $69 \%$ of all the specimens with the $335-\mu \mathrm{m}$ net and the other $31 \%$ with the 600-um net (Table 3). Thus, $60 \%$ of the abundant species were common in both types of nets and the greatest difference in catches was the predominance of Oncaea venusta in the 335- $\mu \mathrm{m}$ net.

Oncaea venusta (15\%) was the predominant species and showed a wide geographic distribution at all stations, averaging 974 ind $10^{-3} \mathrm{~m}^{-3}$ per station, with abundance maxima in the oceanic sector near the Galapagos Islands (Fig. 7a). Subeucalanus pileatus (11\%) followed $O$. venusta in abundance and was found mostly in oceanic waters (central and oceanic sections), with a scant presence off the Ecuadorian coast (Fig. 7b). Pleuro- 
TABLE 1. - Abundance of the 10 most abundant species of copepods (ind $10^{-3} \mathrm{~m}^{-3}$ ) collected with nets of $335 \mu \mathrm{m}$ and $600 \mu \mathrm{m}$ in September and October 2001.

\begin{tabular}{lccc}
\hline Species & Total & Average & Abundance \% \\
\hline Oncaea venusta & 14606 & 974 & 15 \\
Subeucalanus pileatus & 10867 & 724 & 11 \\
Pleuromamma borealis & 8338 & 556 & 9 \\
Subeucalanus crassus & 5149 & 343 & 5 \\
Subeucalanus subtenuis & 4586 & 306 & 5 \\
Scolecithrix danae & 4085 & 272 & 4 \\
Paraeucalanus attenuatus & 3889 & 259 & 4 \\
Clausocalanus farrani & 2608 & 174 & 3 \\
Temora discaudata & 2410 & 161 & 2 \\
Calanus chilensis & 2278 & 152 & 2 \\
& & & \\
Total & 58816 & 3921 & 6 \\
\hline
\end{tabular}

mamma borealis $(9 \%)$ was caught mainly at the stations along the Equatorial Front; these maxima in abundance decreased toward the northern and southern boundaries of the front (Fig. 7c). Subeucalanus crassus (5\%) had a highly homogeneous geographic distribution, peaking at station 14 (Fig. 8a), whereas S. subtenuis (5\%) was scarce at the coastal stations and was found mainly in the oceanic area, peaking at station 12 (Fig. 8b).

Scolecithrix danae (4\%) and Paraeucalanus attenuatus (4\%) were widely distributed in the study area. $S$. danae showed average densities at all stations, with a fairly homogeneous distribution (Fig. 8c), whereas $P$. attenuatus densities were highest in the oceanic area near the Galapagos Islands, with a maximum at station 12 (Fig. 9a). Clausocalanus farrani (3\%) was absent at the stations on the northern edge of the front, with

TABLE 2. - Abundance of 97 remaining species of copepods (ind $10^{-3} \mathrm{~m}^{-3}$ ) collected with nets of $335 \mu \mathrm{m}$ and $600 \mu \mathrm{m}$ in September and October 2001 .

\begin{tabular}{|c|c|c|c|c|c|}
\hline Species & Average & Abundance $\%$ & Species & Average & Abundance $\%$ \\
\hline Pleuromamma abdominalis & 144 & 2 & Acrocalanus andersoni & 8 & 0 \\
\hline Rhincalanus nasutus & 140 & 2 & Farranula rostrata & 8 & 0 \\
\hline Nanocalanus minor & 130 & 2 & Candacia pachydactyla & 7 & 0 \\
\hline Oncaea conifera & 127 & 2 & Euchirella venusta & 6 & 0 \\
\hline Centropages velificatus & 125 & 2 & Labidocera detruncata & 6 & 0 \\
\hline Canthocalanus pauper & 106 & 2 & Scolecithricella abysalis & 6 & 0 \\
\hline Rhincalanus gigas & 96 & 1 & Mecynocera clausi & 5 & 0 \\
\hline Candacia curta & 94 & 1 & Pontellina platychela & 5 & 0 \\
\hline Lucicutia flavicornis & 89 & 1 & Lubbockia aculeata & 4 & 0 \\
\hline Corycaeus dubius & 88 & 1 & Phaena spinifera & 4 & 0 \\
\hline Euchaeta longicornis & 87 & 1 & Euchirella bella & 4 & 0 \\
\hline Acrocalanus longicornis & 85 & 1 & Haloptilus fertilis & 4 & 0 \\
\hline Undinula darwinii & 66 & 1 & Sapphirina stellata & 4 & 0 \\
\hline Undinula vulgaris & 64 & 1 & Scolecitricella tropica & 3 & 0 \\
\hline Clausocalanus mastigophorus & 60 & 1 & Candacia bipinnata & 3 & 0 \\
\hline Oncaea media & 59 & 1 & Rhincalanus cornutus & 3 & 0 \\
\hline Oithona plumifera & 56 & 1 & Scaphocalanus magnus & 3 & 0 \\
\hline Corycaeus clausi & 56 & 1 & Centropages gracilis & 3 & 0 \\
\hline Copilia mirabilis & 54 & 1 & Pontellopsis regalis & 3 & 0 \\
\hline Acartia danae & 53 & 1 & Acrocalanus monachus & 2 & 0 \\
\hline Paraeuchaeta regalis & 50 & 1 & Lophotrix frontalis & 2 & 0 \\
\hline Temora stylifera & 45 & 1 & Haloptilus spiniceps & 2 & 0 \\
\hline Sapphirina opalina & 43 & 1 & Calocalanus stylermis & 2 & 0 \\
\hline Candacia truncata & 38 & 1 & Sapphirina gemma & 2 & 0 \\
\hline Eucalanus inermis & 38 & 1 & Pseudocalanus elongatus & 2 & 0 \\
\hline Paracalanus aculeatus & 35 & 1 & Scaphocalanus subbrevicornis & 2 & 0 \\
\hline Corycaeus ovalis & 35 & 1 & Pontoeciella abyssicola & 1 & 0 \\
\hline Euatideus brady & 34 & 1 & Microsetella rosea & 1 & 0 \\
\hline Heterorhabdus papiliger & 34 & 1 & Scaphocalanus curtus & 1 & 0 \\
\hline Corycaeus crassusculus & 32 & 0 & Pleuromamma xiphias & 1 & 0 \\
\hline Corycaeus latus & 30 & 0 & Lucicutia ovalis & 1 & 0 \\
\hline Calocalanus pavus & 28 & 0 & Haloptilus acutifrons & 1 & 0 \\
\hline Sapphirina nigromaculata & 24 & 0 & Copilia vitrea & 1 & 0 \\
\hline Clausocalanus arcuicornis & 23 & 0 & Euchirella pulchra & 1 & 0 \\
\hline Labidocera acuta & 23 & 0 & Oithona nana & 1 & 0 \\
\hline Euchaeta rimana & 23 & 0 & Pachos punctatum & 1 & 0 \\
\hline Scolecithrix bradyi & 20 & 0 & Sapphirina angusta & 1 & 0 \\
\hline Haloptilus longicornis & 20 & 0 & Euchaeta acuta & 1 & 0 \\
\hline Euchaeta wolfendeni & 19 & 0 & Candacia varicans & 1 & 0 \\
\hline Corycaeus flaccus & 18 & 0 & Pontella sp. & 1 & 0 \\
\hline Candacia catula & 18 & 0 & Scaphocalanus echiniatus & 1 & 0 \\
\hline Corycaeus speciosus & 17 & 0 & Candacia cheurura & 1 & 0 \\
\hline Paracalanus cf. indicus & 14 & 0 & Eugaptilus hecticus & 0 & 0 \\
\hline Pleuromamma gracilis & 13 & 0 & Haloptilus austini & 0 & 0 \\
\hline Corycaeus agilis & 13 & 0 & Augaptilus longicaudatus & 0 & 0 \\
\hline Sapphirina intestinata & 10 & 0 & Candacia simplex & 0 & 0 \\
\hline Oithona spinirostris & 10 & 0 & Acartia tonsa & 0 & 0 \\
\hline Eucalanus elongatus & 9 & 0 & Sapphirina metallina & 0 & 0 \\
\hline Corycaeus giesbrechti & 9 & 0 & Total & 2620 & 40 \\
\hline
\end{tabular}


TABle 3. - Percentage of the 10 most abundant species obtained with the nets of $335 \mu \mathrm{m}$ and $600 \mu \mathrm{m}$ in September and October 2001.

\begin{tabular}{|c|c|c|c|c|}
\hline No & $600 \mu \mathrm{m}$ & Abundance $\%$ & $335 \mu \mathrm{m}$ & Abundance $\%$ \\
\hline 1 & Subeucalanus pileatus & 14 & Oncaea venusta & 21 \\
\hline 2 & Subeucalanus crassus & 9 & Pleuromamma borealis & 10 \\
\hline 3 & Scolecithrix danae & 8 & Subeucalanus pileatus & 10 \\
\hline 4 & Subeucalanus subtenuis & 7 & Subeucalanus subtenuis & 4 \\
\hline 5 & Paraeucalanus attenuatus & 6 & Subeucalanus crassus & 4 \\
\hline 6 & Pleuromamma borealis & 5 & Clausocalanus farrani & 3 \\
\hline 7 & Pleuromamma abdominalis & 5 & Paraeucalanus attenuatus & 3 \\
\hline 8 & Rhincalanus nasutus & 5 & Oncaea conifera & 3 \\
\hline 9 & Calanus chilensis & 5 & Scolecithrix danae & 2 \\
\hline 10 & Temora discaudata & 4 & Centropages velificatus & 2 \\
\hline & 97 Remaining species & 32 & 97 Remaining species & 38 \\
\hline
\end{tabular}
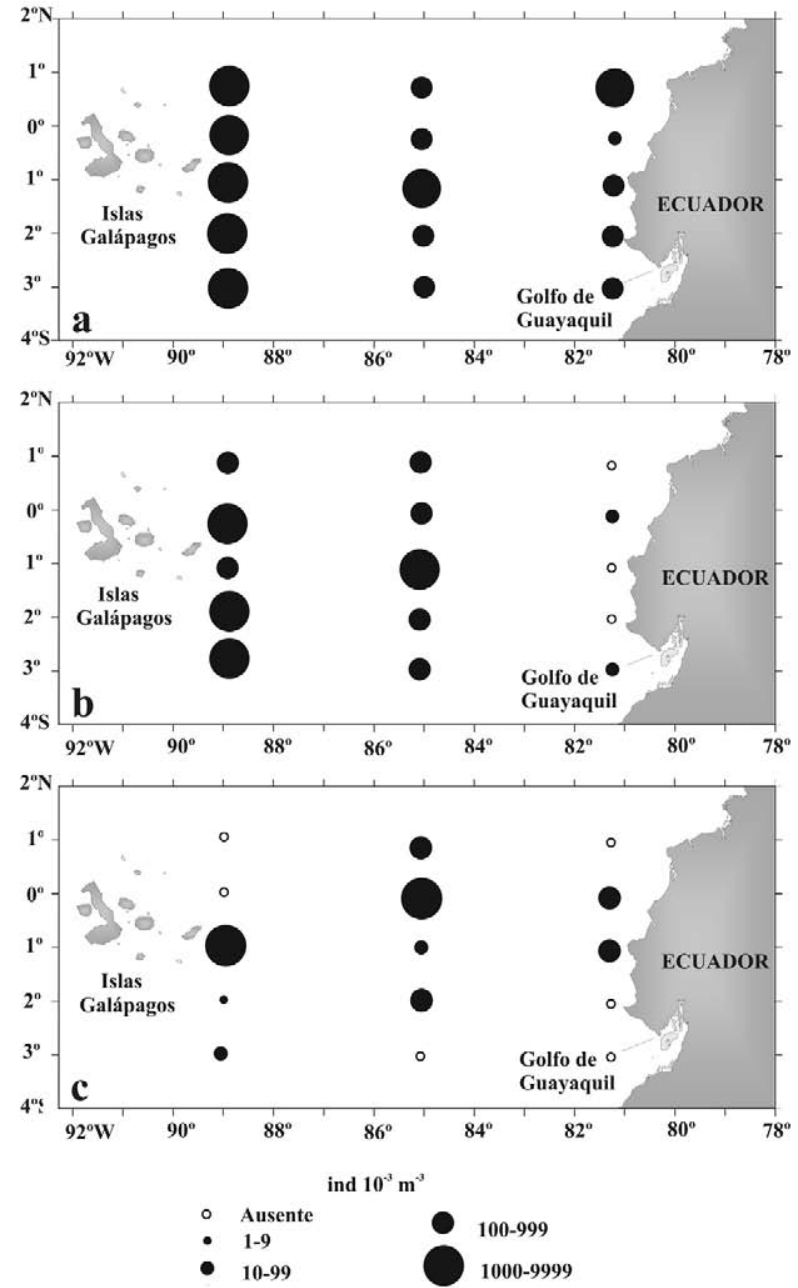

FIG. 7. - Geographic distribution of a) Oncaea venusta, b) Subeucalanus pileatus and c) Pleuromamma borealis in September and October 2001.

maxima to the south of the front in association with cold subtropical waters (Fig. 9b). Temora discaudata (2\%) showed a wide geographic distribution, peaking to the east of the Galapagos Islands, and was associated with the stations on the northern edge of the front (Fig. 9c). However, the distribution of Calanus chilensis (2\%) was restricted to the cold subtropical waters south of the Equatorial Front (Fig. 10).
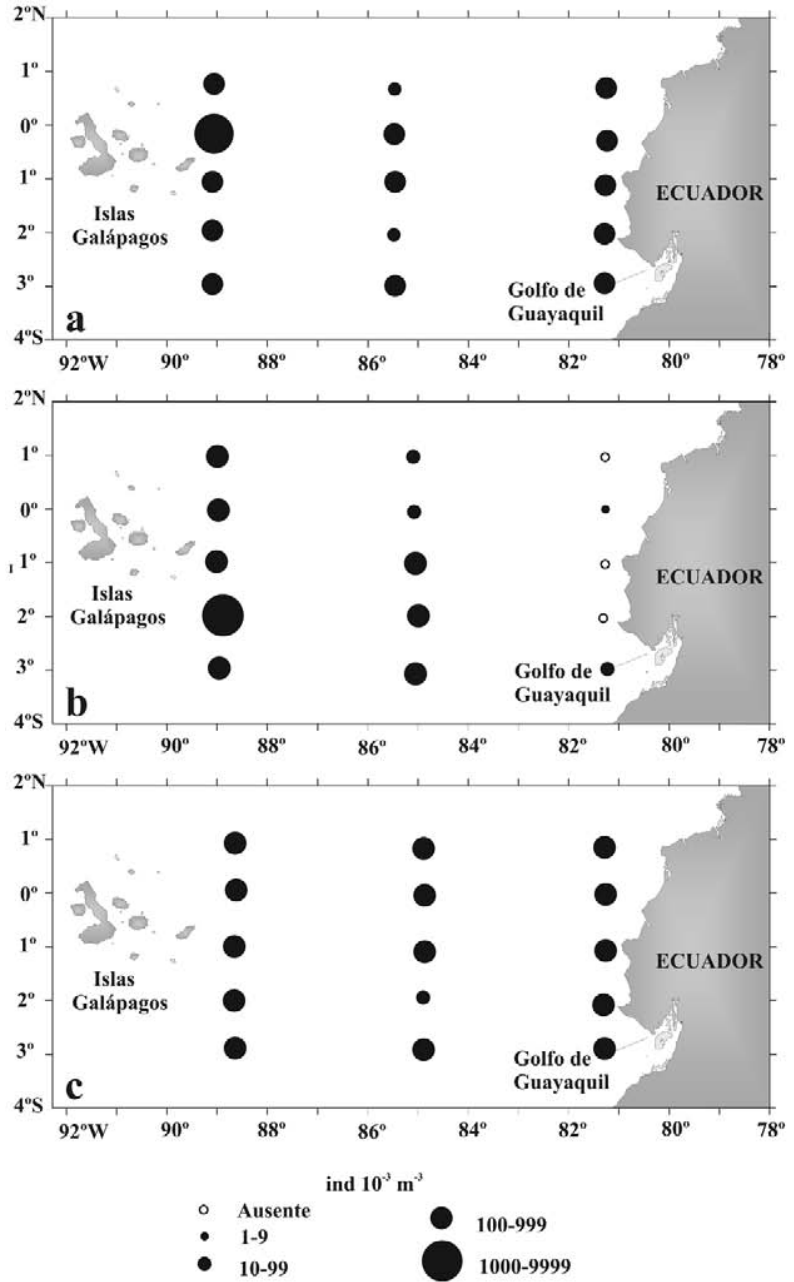

FIG. 8. - Geographic distribution of a) Subeucalanus crassus, b) Subeucalanus subtenuis and c) Scolecithrix danae in September and October 2001.

When considering the individual abundance results obtained for each net $(335$ and $600 \mu \mathrm{m})$, we must include four additional species with low abundance values (Table 3 ). For the $335-\mu \mathrm{m}$ net, these were $O$. conifera (3\%), with the greatest densities at the stations on the southern border of the Equatorial Front (Stations 1-2, 9-12), and Centropages velificatus (2\%), with a wide geographic distribution 

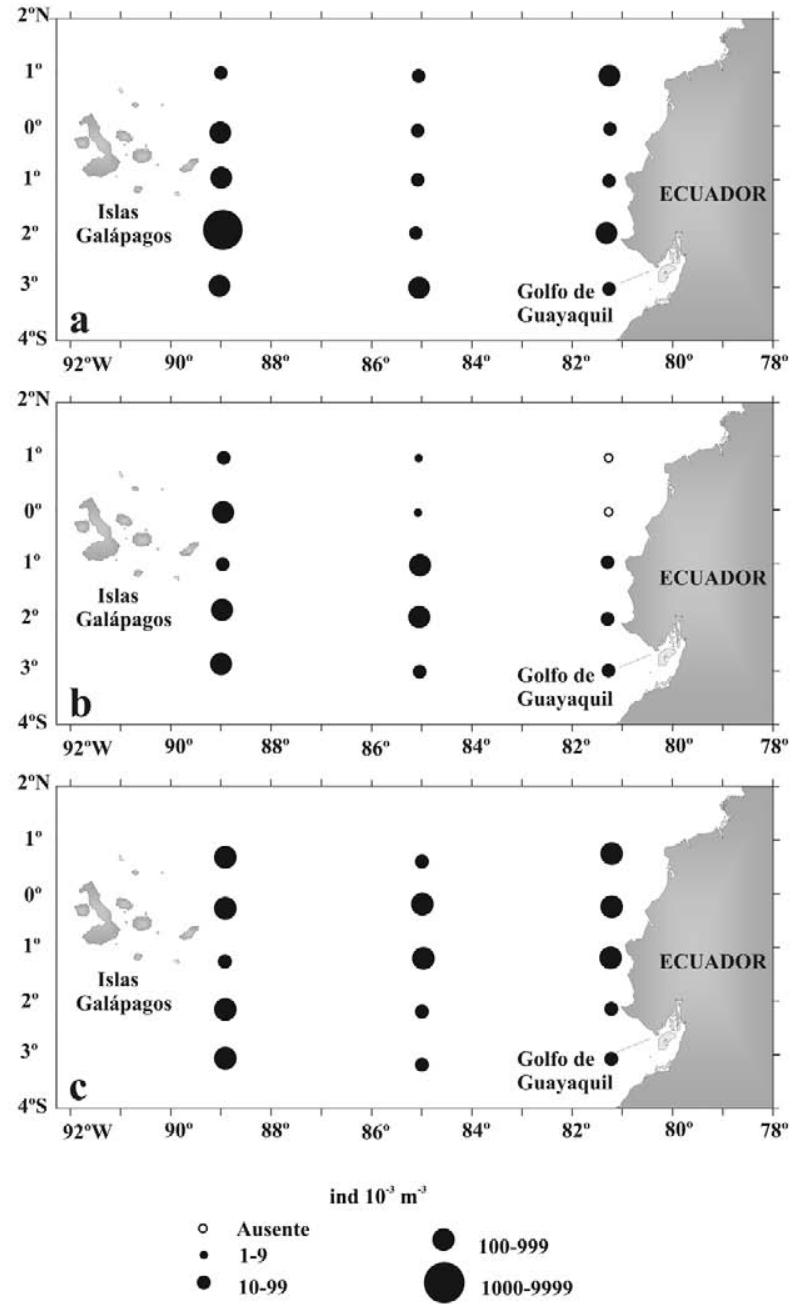

FIG. 9. - Geographic distribution of a) Paraeucalanus attenuatus, b) Clausocalanus farrani and c) Temora discaudata in September and October 2001.

and maxima at the stations in the central area of the Equatorial Front. With the $600-\mu \mathrm{m}$ net, these were Pleuromamma abdominalis (5\%), with maximum densities in the $85^{\circ} \mathrm{W}$ section that declined towards the northern and southern limits of the front, and

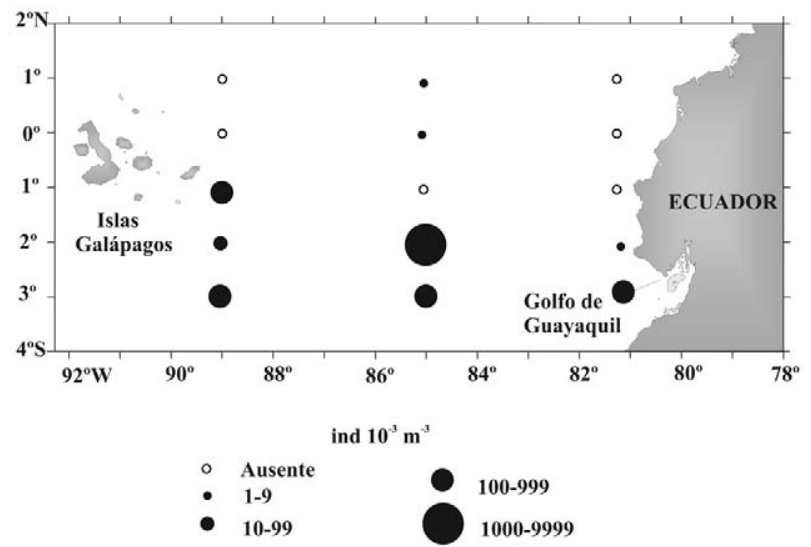

FIG. 10. - Geographic distribution of Calanus chilensis in September and October 2001.

Rhincalanus nasutus (5\%), with a wide geographic distribution and higher densities in the central part of the front.

\section{Similarity index}

The results of the Bray-Curtis index with Ward's cluster analysis, represented by the 10 most abundant species, revealed three groups of species in areas with different oceanographic characteristics (Fig. 11). Group 1 included Oncaea venusta, Temora discaudata, Subeucalanus crassus y Subeucalanus. pileatus, the first three having the highest abundance associated with warm tropical waters from the north, while Subeucalanus pileatus showed its maximum eastward of the Galapagos Islands associated with an upwelling event. Group 2 was constituted by Subeucalanus subtenuis, Paraeucalanus attenuatus, Clausocalanus farrani and Scolecithrix danae, which revealed their highest abundance in the station to the east of the Galapagos Islands. Group 3 consisted of Pleuromamma borealis and Calanus chilensis, which were absent on the northern edge of the Front and had maxima located on the southern edge and in the central sector of the Equatorial Front, respectively.

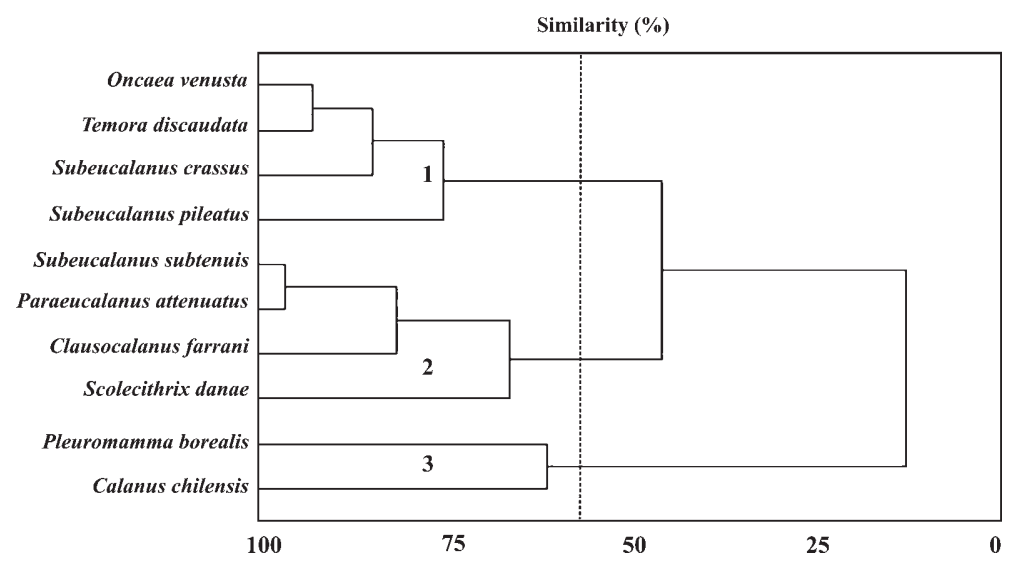

FIG. 11. - Similarity dendrograms between species calculated by Bray-Curtis Index. 
$\mathbf{8 0 0} \cdot \mathrm{P}$. TUTASI et al.

TABLE 4. - Chi-square test $\left(\chi^{2}\right)$ based on the extraction of successive canonical variables.

\begin{tabular}{lccccc}
\hline Root & $R$ canonical & $\chi^{2}$ & df & \multicolumn{1}{c}{$P$} & Lambda \\
\hline 0 & 0.933203 & 89.01135 & 30 & 0.00000001 & 0.017493 \\
1 & 0.874296 & 43.97927 & 18 & 0.0005850 & 0.135463 \\
\hline
\end{tabular}

\section{Canonical correlation}

The canonical correlation index between the abiotic variables (weighted temperature and salinity values) and the biotic variables (corresponding to the 10 most abundant species) was $R=0.93(P<0.0001)$ for the first canonical variable. The chi-squared test $\left(\chi^{2}\right)$ showed significant values for both canonical roots (Table 4).

\section{DISCUSSION}

In September-October 2001, while slight increases in sea surface temperature (SST) anomalies were observed in central Equatorial Pacific $\left(2^{\circ} \mathrm{N}-2^{\circ} \mathrm{S}\right)$, announcing the end of La Niña event 2001, the eastern South Pacific, including the coasts of Ecuador, Peru and Chile $\left(1-20^{\circ} \mathrm{S}\right)$, still evidenced negative anomalies $\left(-0.5\right.$ to $\left.-1.5^{\circ} \mathrm{C}\right)$. In agreement with historical maps published by NOAA (2001) for the eastern Equatorial Pacific (El Niño area $1+2)$, the SST was lower $\left(-1.5^{\circ} \mathrm{C}\right)$ than the historical averages for September-October. Moreover, during the same period, the thermal subsurface structure off La Libertad and Manta in Ecuador showed a rise in the isotherms, a characteristic feature of La Niña events (ERFEN, 2001).

Two of the main currents present in the study area were observed in the geostrophic velocity field (Fig. 4). There was evidence of a weak westward current between $1^{\circ}$ and $2^{\circ} \mathrm{N}$, which could be a part of the South Equatorial Current, and an eastward current flowing at about $-2^{\circ}$ and $-3^{\circ} \mathrm{S}$, which could be associated with a small coastal branch of the Equatorial Undercurrent (EUC) extended to the surface, as suggested by Lukas (1986). A counter-clockwise eddy at about $1^{\circ} \mathrm{N}$ and $90^{\circ} \mathrm{W}$ could have been promoting upwelling in the northwestern region of the sampling. The copepod fauna in the study area was made up of 107 species, complementing the previous work of Tutasi (2001), who identified 97 species for the coastal zone of Ecuador in the same study period. Our results offer a broader view of the distribution and abundance of this taxon in the waters of the eastern equatorial Pacific, suggesting that abundance of copepods was related to the existence of the Equatorial Front and to upwelling processes occurring during sampling. Patterns of circulation of two main oceanic currents and evidence of mesoscale eddies in the region might indicate upwelling. Cornejo and Antezana (1979), Jiménez and Bonilla (1980), Jiménez (1983), Córdova (1989), Torres and Tapia (2000), Torres et al. (2004), observed similar distribution patterns of both phytoplankton and zooplankton in the study area, providing important information about the close relationship between the distribution patterns of taxa to oceanographic conditions of the Equatorial Front, which would strengthen our results.

It is known that equatorial upwelling produces an area of high biological productivity around the Galápagos Islands that is intensified during cold La Niña events (Torres and Tapia, 2000). In this work, abundance was highest at the stations on the southern border of the Equatorial Front (Stations $11,12,89^{\circ} \mathrm{W}$ section), and small cores of abundance were found in the oceanic area $\left(85^{\circ} \mathrm{W}\right)$. Upwelling-favourable wind conditions dominated during our study, which could explain the high copepod abundance observed on the southern side of the Galápagos Islands. These patterns could be attributed to 1) an augmented contribution of cold waters and negative anomalies in temperature $\left(19-21^{\circ} \mathrm{C}\right)$ and salinity $(34.5-35.0)$ resulting from an upwelling process triggered by a remnant of the Equatorial Undercurrent (Fig. 4) moving eastward past the Galápagos Islands, 2) the oceanic branch of the Humboldt Current, and upwelling driven from southerly winds, and 3) the contribution of upwelling from small eddies present in the southern region, which favours abundance of copepods. Such conditions coincide with high values of chlorophyll $\left(1.1 \mathrm{mg} \mathrm{m}^{-3}\right)$ recorded in the same area in September-October 2001 (Torres et al., 2004), with low patches $\left(>0.5 \mathrm{mg} \mathrm{m}^{-3}\right)$ in the ocean $\left(85^{\circ} \mathrm{W}\right)$ associated with highest biomass of diatoms and resulting from an upwelling process triggered by a remnant of the Equatorial Undercurrent passing through the Galapagos Islands. Furthermore, these conditions indicate that this atypical event was associated with the overall cooling of La Niña and/or bloom waters moving from the west toward the continent, favouring the availability of pelagic resources off the Ecuadorian coast.

Ten of the 107 species identified constituted $60 \%$ of all the copepods analyzed (Table 1). Their distribution and abundance were related to the different oceanographic conditions that occur in the area. Depending on the mesh size used, the most abundant species were Oncaea conifera and Centropages velificatus (335- $\mu \mathrm{m}$ mesh) and Pleuromamma abdominalis and Rhincalanus nasutus (600- $\mu \mathrm{m}$ mesh); all these species are characteristic of cold subtropical waters and have been recorded from Peruvian and Chilean waters (Björnberg, 1981; Hsieh et al., 2004; Jiménez and Lavaniegos, 2004; López and Palomares, 2006; Ayón et al., 2008). $O$. conifera, $P$. abdominalis and $R$. nasutus are common in the sub-Antarctic waters of the Humboldt Current System off the Peruvian and Chilean coasts (Palma and Kaiser, 1993; Hidalgo and Escribano, 2001; Ayón et al., 2008). However, in this study, abundance was highest in the central zone of the Equatorial Front, indicating considerable displacement of the aggregations: from the eastern South Pacific to the equatorial Pacific.

In this study we used two simple conical nets joined together (335- $\mu \mathrm{m}$ and $600-\mu \mathrm{m}$ mesh openings), in order to have a greater appreciation of copepod communities. However, we believe that this kind of mesh presumably, miss the smaller copepod species, for this reason 
we consider that is very important to make future sampling using fine-mesh nets has greatly increased our estimation of diversity, abundance, biomass and production of small copepods within the copepod community, because of the important role played by these organisms in ocean productivity, not just as consumers of phytoplankton and important components of the microbial loop, but also as important indicators of oceanographic changes (Turner, 2004; Temperoni, 2008; McKinnon et al., 2008).

The results of the Bray-Curtis Index with Ward cluster analysis showed that the 10 most abundant species grouped by similarity and abundance in three group covered geographic areas associated with oceanographic conditions that typify the Equatorial Front and upwelling processes due to the influence of the weak La Niña event of 2001 (NOAA, 2001). The species that best defined the conditions of the Equatorial Front were Oncaea venusta, Pleuromamma borealis, and Calanus chilensis, all oceanic in origin (Björnberg, 1981).

Of these species, Calanus chilensis constituted Group 3 and best characterized the southern edge of the Equatorial Front (Stations 1-4, 9, 10). This species occupied the largest part of this area and was highly influenced by subtropical waters with low temperatures and salinity. This species is typical of the Humboldt Current System (Giraldo et al., 2002; Escribano et al., 2004; Hidalgo and Escribano, 2007; Ayón et al., 2008) and location of catches in this area indicates a displacement from the coast of Chile-Peru to Ecuador, coinciding with the proposal of Arcos and Fleminger (1986). However, in this study, C. chilensis distribution extended farther northward than in normal years (Arcos and Fleminger, 1986), offering evidence that the influence of the Humboldt Current reached farther north in the equatorial Pacific during the cold event of 2001. These results suggest that $C$. chilensis could be used as a baseline to indicate future La Niña events in waters of the eastern equatorial Pacific. This hypothesis should be corroborated in future studies.

The transition zone of the Equatorial Front, between warm tropical waters from the north and cold sub-tropical waters from the south is characterized by peaks of Pleuromamma borealis (Stations 6-8, 13) that decrease latitudinally towards the northern and southern edges of the front. It is important to note that $P$. borealis was not found on the northern edge of the Equatorial Front, with warm tropical waters, but showed a greater preference for low-temperature waters, confirming the description given by Björnberg (1981). These results differ from the findings of McGowan (1971) and Arcos and Fleminger (1986) for normal years, when Rhincalanus nasutus was the predominant species in this area; the decline of this species was due to the greater northward influx of cold waters brought on from the south.

The warm tropical waters on the northern edge of the Equatorial Front (Stations 5, 14, 15) had low salinity and were characterized by Oncaea venusta, Temora discaudata, and Subeucalanus crassus. These species are typical of tropical and oceanic waters (Björnberg, 1981; Jiménez and Lavaniegos, 2004), particularly S. crassus, which is characteristic of equatorial waters (McGowan, 1971). The highly abundant $O$. venusta was the species that best defined this area. This agrees with the description of waters from the eastern Pacific (Dessier and Donguy, 1985), where $O$. venusta was closely tied to warm tropical waters on the northern edge of the Equatorial Front, where it was very abundant. Moreover, Hwang and Turner (1995) associated O. venusta with warm waters in the western Pacific Ocean, indicating its preference for warmer waters. This species could be considered as an indicator of the influence of warm equatorial surface waters in this area.

The eastern side of the Galápagos Islands affected by upwelling regime was characterized by Subeucalanus subtenuis, Paraeucalanus attenuatus, Clausocalanus farrani, and Scolecithrix danae, typical species in equatorial and sub-tropical waters (McGowan, 1971; Björnberg, 1981; Jiménez and Lavaniegos, 2004) and by Subeucalanus pileatus, a species characteristic of coastal waters (Jiménez and Lavaniegos, 2004). The area was best defined by Subeucalanus subtenuis, which was located at the southwestern limit of the Equatorial Front. This species is typical of tropical eutrophic waters (Björnberg, 1981) and waters with recent blooms that are rich in nutrients, following $S u b$ eucalanus pileatus in abundance. These results differ from those of Arcos and Fleminger (1986), who found maxima of these species in the coastal zone.

The analysis of canonical correlation revealed that $91 \%$ of the variability in the distribution and abundance of the copepod species in September-October 2001 was explained by two physical parameters: temperature and salinity. However, it was not possible to determine which of these had a greater influence on the distribution and abundance of the copepods because of the limited number of stations sampled.

In summary, copepod composition, abundance, and distribution in the eastern Equatorial Pacific were highly related to the intensification of the Equatorial Front and to upwelling processes, conditions associated with La Niña event in this part of the Central Pacific.

\section{ACKNOWLEDGEMENTS}

The authors thank the Oceanographic Institute of the Ecuadorian Navy (INOCAR) for valuable field assistance and for providing the samples that were analyzed in the present study. We are also indebted to three anonymous reviewers for helping us to improve the paper.

\section{REFERENCES}

Arcos, F. - 1978. Distribución de la biomasa planctónica y copépodos en la parte interior del Golfo de Guayaquil. Rev. Com. Perm. Pac. Sur, 9: 41-50.

Arcos, F. and A. Fleminger. - 1986. Distribution of filter-feeding calanoid copepods in the eastern Equatorial Pacific. CalCOFI 
Rep., 27: 170-187.

Ayón, P., M.I. Criales-Hernandez, R. Schwamborn and H.J. Hirche. - 2008. Zooplankton research off Peru: a review. Prog. Oceanogr., 79(2-4): 238-255.

Beaugrand, G., P.C. Reid, F. Ibanez, J.A. Lindley and M. Edwards. - 2002. Reorganization of North Atlantic marine copepod biodiversity and climate. Science, 296(5573): 1692-1694.

Björnberg, T. - 1981. Copepoda. In: E. Boltovskoy (ed.). Atlas del zooplancton del Atlántico Sudoccidental. Instituto Nacional de Investigación y Desarrollo Pesquero, Mar del Plata, pp. 587-679.

Bloom, S.A. - 1981. Similarity indices in community studies: potential pitfall. Mar. Ecol. Prog. Ser., 5: 125-128.

Brinton, E. - 1962. The distribution of Pacific euphausiids. Bull Scripps Inst. Oceanogr., 8(2): 51-270.

Carrasco, S. and H. Santander, 1987. The El Niño event and its influence on the zooplankton off Peru. J. Geophys. Res., 92(C13): 14405-14410.

Chen, Y. - 1986. The vertical distribution of some pelagic copepods in the eastern tropical Pacific. CalCOFI Rep., 27: 205-227.

Córdova, J. - 1989. Distribución de la clorofila "a" con relación al frente ecuatorial durante agosto de 1988. Acta Oceanogr. Pac., 5(1): $9-13$

Cornejo, M. and T. Antezana, - 1979. Distribución de los eufáusidos epipelágicos del Ecuador y su validez como indicadores de masas de agua (Zooplancton, Crustacea). Acta Oceanogr. Pac., 3(1): $1-30$.

Costello, J.H., B.K. Sullivan and D.J. Gifford. - 2006. A physicalbiological interaction underlying variable phonological responses to climate change by coastal zooplankton. J. Plankton Res., 28: 1099-1105.

Dawson, J. and G. Knatz. - 1980. Illustrated key to the planktonic copepod of San Pedro Bay, California. Allan Hancock Found, Tech. Rep., 2: 1-106.

Dessier, A. and J.R. Donguy. - 1985. Planktonic copepods and environmental properties of the eastern Equatorial Pacific: seasonal and spatial variations. Deep-Sea Res., 32(9): 1117-1133.

Dessier, A., and J. Donguy. - 1987. Response to El Niño signals of the epiplanktonic copepod population in the Eastern Tropical Pacific. J. Geophys. Res., 92(C13): 14393-14403.

ERFEN. - 2001. Evento El Niño 2001-2002 y sus perspectivas de ocurrencia. Estudio Regional del Fenómeno El Niño (ERFEN) Comité Nacional, Ecuador. Informe Técnico, 3: 1-5.

Escribano, R., G. Daneri, L. Farías, V. Gallardo, H. González, D. Gutiérrez, C. Lange, C. Morales, O. Pizarro, O. Ulloa and M. Braun. - 2004. Biological and chemical consequences of the 1997-1998 El Niño in the Chilean coastal upwelling system: a synthesis. Deep-Sea Res., 2(51): 2389-2411.

Giraldo, A., R. Escribano and V. Marín. - 2002. Spatial distribution of Calanus chilensis off Mejillones Peninsula (northern Chile): ecological consequences upon coastal upwelling, Mar. Ecol. Prog. Ser., 230: 225-234.

Grice, G. - 1961. Calanoid copepods from Equatorial waters of the Pacific Ocean. Fish. Bull., 61: 172-241.

Hair, J., R. Anderson, R. Tatham and C. William. - 1998. Multivariate Data Analysis 5th edition. Adapted from Chapter 8. Prentice Hall, Inc. pp 1-29.

Hidalgo, P. and R. Escribano. - 2001. Succession of pelagic copepod species in coastal waters off northern Chile: The influence of the 1997-98 El Niño. Hydrobiologia, 453/454: 153-160.

Hidalgo, P. and R. Escribano. - 2007. Coupling of life cycles of the copepods Calanus chilensis and Centropages brachiatus to upwelling induced variability in the central-southern region of Chile. Prog. Oceanogr., 75: 501-517.

Hooff, R. and W. Peterson. - 2006. Copepod biodiversity as an indicator of changes in ocean and climate conditions of the northern California current ecosystem. Limnol. Oceanogr., 51(6): 2607-2620.

Hsieh, CH., T. Chiu and C. Shih. - 2004. Copepod diversity and composition as indicators of intrusion of the Kuroshio Branch Current into the northern Taiwan Strait in spring 2000. Zool Stud., 43(2): 393-403.

Hwang, J. and J. Turner. - 1995. Behavior of cyclopoid, harpacticoid and calanoid copepods from coastal waters of Taiwan. Mar. Ecol., 16: 207-216.

Jiménez, R. - 1983. Variabilidad de las condiciones oceanográficas en el área del Frente Ecuatorial. FAO, Inf. Pesc., 29(2): 131-150.

Jiménez, R. - 2000. El Niño y sus efectos en las comunidades planctónicas: Centro de Biodiversidad Marina Golfo de Guayaquil CEBIMAR. Ministerio del Ambiente. No 1. pp. 1-19.

Jiménez, R. and D. Bonilla. - 1980. Composición y distribución de la biomasa del plancton en el Frente Ecuatorial. Acta Oceanogr. Pac., 1(1): 19-64.

Jiménez, L. and B. Lavaniegos. - 2004. Changes in dominance of copepods off Baja California during the 1997-1999 El Niño and La Niña. Mar. Ecol. Prog. Ser., 277: 147-165.

López, G. and R. Palomares. - 2006. Estructura de la comunidad de copépodos bahía Magdalena, México, El Niño 1997-1998. Rev. Bio. Mar. Oceanogr., 41(1): 63-76.

Lukas, R. -1986. The termination region of the Ecuatorial Undercurrent in the eastern Pacific. Prog. Oceanogr., 16: 63-90.

McGowan, J.A. - 1971. Oceanic biogeography of the Pacific. In: B.M. Funnell and W.R. Riedel (eds.). The micropaleontology of oceans. Cambridge University Press, London, pp. 3-74.

Mazzocchi, M., G. Zagami, A. Ianora, L. Guglielmo, N. Crescenti and J. Hure. - 1995. Copepods. In: L. Guglielmo and A. Ianora (eds.). Atlas of marine zooplankton Straits of Magellan. Springer Verlag, Berlin, pp. 1-279.

McKinnon, A. D., S. Duggan, J. H. Carleton and R. BöttgerSchnack. - 2008. Summer planktonic copepod communities of Australia's North West Cape (Indian Ocean) during the 199799 El Niño/La Niña. J. Plankton Res., 30(7): 839-855.

NOAA. - 2001. October. Climate Prediction Center. National Centers for Environmental Prediction. NOAA/ National Weather Service. www.cpc.ncep.noaa.gov. Camp Spring, MD.

Okuda, T., R. Trejos, M. Valencia and A. Rodríguez. - 1983. Variación estacional de la posición del Frente Ecuatorial y su efecto sobre la fertilidad de las aguas superficiales ecuatorianas. Acta Oceanogr. Pac., 2(1): 53-84.

Palma, S. and K. Kaiser. - 1993. Plancton Marino de Aguas Chilenas. Universidad Católica de Valparaíso. Facultad de Recursos Naturales. Escuela de Ciencias del Mar, pp. 87-92.

Philander, G. - 1990. El Niño, La Niña and the Southern Oscillation. Int. Geophys. Ser., 49: 1-289.

Rosales, S. - 1992. Estructura comunitaria horizontal de copépodos calanoideos y características hidrográficas entre los Vilos y Valparaíso, durante enero de 1990. Tesis de Oceanografía. Escuela de Ciencias del Mar, Pontificia Universidad Católica de Valparaíso, 63 pp.

Sharp, G.D. - 2004. Cambio climático y pesquerías regionales en el futuro: análisis en colaboración. Dirección de Recursos Pesqueros. FAO, Rome, Doc. Téc. Pesca, 452: 1-89.

Temperoni, B. - 2008. Variación estacional de la producción secundaria de Oithona nanna (Copepoda: Cyclopoida) en aguas costeras bonaerenses. Instituto Nacional de Investigaciones Pesqueras, Mar del Plata, 73 pp.

Torres, G. and M. Tapia. - 2000. Distribución del fitoplancton y su comportamiento en el afloramiento en las islas Galápagos. Acta Oceanogr. Pac., 10(1): 137-150.

Torres, G., M. Mero, T. Calderón, V. Franco and E. Salazar. - 2004. Relación fitoplancton-zooplancton en el Pacífico Ecuatorial (Ecuador), durante septiembre 2001. Acta Oceanogr. Pac., 12(1): 51-61.

Turner, J.T. - 2004. The importance of small planktonic copepods and their roles in pelagic marine food webs. Zool. Stud., 43(2): 255-266.

Tutasi, P. - 2005. Identificación de copépodos (Crustacea: Zooplancton) en aguas costeras ecuatorianas con relación al evento La Niña (Septiembre de 2001). Tesis de Grado. Escuela de Biología, Universidad de Guayaquil, Guayaquil, 275 pp.

Wilson, C. - 1932. The copepods of the Woods Hole Region, Massachusetts. Smithson. Inst. U.S. Natl. Mus.. Bull., 158: 1-635.

Wooster, W. - 1969. Equatorial front between Peru and Galapagos. Deep-Sea Res. Suppl. 16: 407-419.

Wyrtki, K. - 1967. Circulation of water masses in the Eastern Equatorial Pacific Ocean. Int. J. Oceanol. Limnol., 1: 117-147.

Zambrano, E. - 1998. Un análisis de la estructura termal de la estación costera "La Libertad" y su relación con los Eventos ENOS. Acta Oceanogr. Pac., 9(1): 1-8.

Scient. ed.: A. Ianora.

Received November 5, 2010. Accepted May 6, 2011.

Published online October 18, 2011. 